Article

\title{
Characterization of Essential Oils Obtained from Abruzzo Autochthonous Plants: Antioxidant and Antimicrobial Activities Assessment for Food Application
}

\author{
Marika Pellegrini, Antonella Ricci * (D), Annalisa Serio ${ }^{(\mathbb{D}}$, Clemencia Chaves-López, \\ Giovanni Mazzarrino, Serena D'Amato, Claudio Lo Sterzo and Antonello Paparella iD $^{\circ}$ \\ Facoltà di Bioscienze e Tecnologie Agro-Alimentari e Ambientali, Università degli Studi di Teramo, \\ Via R. Balzarini 1, 64100 Teramo, Italy; mpellegrini@unite.it (M.P.); aserio@unite.it (A.S.); \\ cchaveslopez@unite.it (C.C.-L.); g.mazzarrino@virgilio.it (G.M.); sdamato@unite.it (S.D.); \\ closterzo@unite.it (C.L.S.); apaparella@unite.it (A.P.) \\ * Correspondence: aricci@unite.it; Tel.: +39-0861-266-904
}

Received: 21 December 2017; Accepted: 30 January 2018; Published: 2 February 2018

\begin{abstract}
In the present study, the essential oils (EOs) of some officinal plants from Abruzzo territory (Italy) were evaluated for their antimicrobial and antioxidant activities and their volatile fraction chemical characterization. The EOs were extracted from Rosmarinus officinalis, Origanum vulgare, Salvia officinalis, Mentha piperita, Allium sativum, Foeniculum vulgare, Satureja montana, Thymus vulgaris and Coriandrum sativum seeds. The antimicrobial activity was screened against thirteen Gram-positive and Gram-negative strains to determine the Minimal Inhibitory Concentration (MIC). The total phenolic content (TPC) and the antioxidant capacity (AOC) were assessed by means of Folin-Ciocâlteu method, and Trolox Equivalent Antioxidant Capacity with 2,2'-azinobis-(3-ethylbenzothiazoline-6-sulfonic acid (TEAC/ABTS), Ferric Reducing Antioxidant Power (FRAP) and 2,2-diphenyl-1-picrylhydrazyl (DPPH) assays respectively. Among the nine EOs tested, T. vulgaris, S. montana, O. vulgare and C. sativum EOs showed MIC values ranging from 0.625 to $5 \mu \mathrm{L} / \mathrm{mL}$. The AOC and TPC results for these species were also interesting. The major components for these EOs were thymol for T. vulgaris (44\%) and O. vulgare (40\%), linalool (77\%) for C. sativum, and carvacrol for S. montana ( $54 \%)$. The results allowed the study to establish that these EOs are good candidates for potential application as biopreservatives in foods and/or food manufacture environments.
\end{abstract}

Keywords: essential oils; antimicrobial; antioxidant; GC-MS

\section{Introduction}

Food spoilage can be defined as the alteration of a product due to microbial, chemical, or physical mechanisms that lead a food to become undesirable or unacceptable for human consumption [1]. In food products manufacture, many effective preservation strategies are applied against food spoilage, involving mainly the employment of synthetic preservatives. However, the increasing negative consumer perception of synthetic additives and the worldwide growing problem of allergies, is causing the food industry to search for more effective preservation strategies [2].

An alternative strategy to synthetic chemical preservatives is represented by the employment of essential oils (EOs). Commonly employed in foods as aromatizing and flavoring agents [2], these plant volatile fractions can be exploited by the food industry for their antimicrobial [3,4] and antioxidant [5] properties. EOs, in fact, possess the ability to permeabilize the membrane of microorganisms, with consequent loss of vital intracellular constituents and interruption of the cellular metabolism and 
enzyme kinetics [6]. In addition, terpenes and terpenoids, alkaloids and phenolic compounds present in these volatile fractions are recognized antioxidant substances [7-9].

According to European Pharmacopeia, the EOs can be obtained by steam distillation or by hydrodistillation [10] and their yield and composition are influenced by the presence of several factors, such as location, climate, plant species, methodology and experimental procedures [11,12].

In the Italian territory, Abruzzo is one of the central area regions characterized by a multitude of environments and microclimates and with the richest flora of Italy and the Mediterranean basin [13]. In the Abruzzo territory, different plant species are cultivated and exploited for their therapeutic and alimentary properties [14]; among them, Rosmarinus officinalis, Origanum vulgare, Salvia officinalis, Mentha piperita, Allium sativum, Foeniculum vulgare, Satureja montana, Thymus vulgaris, and Coriandrum sativum, are the aromatic plants commonly employed in the Mediterranean diet [15-17].

In scientific literature, different data that showed the antimicrobial and antioxidant potentials of the EOs recovered from these vegetal species are reported [18-21]. However, limited data are available for the EOs obtained from these Abruzzo plant species. In this perspective, the aims of the study were the extraction and the Gas Chromatography-Mass Spectrometry (GC-MS) characterization of the EOs from Abruzzo officinal plants and assessment of their antimicrobial properties against several food-borne strains, as well as their antioxidant capacities and total phenolic contents.

\section{Materials and Methods}

\subsection{Plant Material}

The matrices were obtained from Abruzzo territory farmers. The cultures were obtained with organic agriculture and after the harvesting, the matrices were dried on fields and stored at room temperature in dry and dark conditions for few days. The matrices were then transferred in the laboratory for extractions and analyses. Regarding A. sativum, after the harvesting, the bulbs were transferred in the laboratory, cleaned and the resultant cloves were vacuum-packed and refrigerated until extraction and analyses.

\subsection{Essential Oils Extraction}

Essential oils were extracted from the matrices by means of an E0105 12 lt PLUS Essential Oils Extractor (Albrigi Luigi Srl, Verona, Italy). For all plant materials, after two hours of distillation, no significant volume increase was observed in the collector tube, thus all matrices were subjected to $2 \mathrm{~h}$ steam distillation, except for garlic cloves which were subjected to $2 \mathrm{~h}$ hydrodistillation. After extraction, the EOs were transferred to an amber glass vial with anhydrous sodium sulfate (Sigma Aldrich, Saint Louis, MO, USA), conditioned with argon and sealed. Each matrix extraction was conducted in triplicate. The collected EOs were stored under refrigeration at $4{ }^{\circ} \mathrm{C}$.

\subsection{Chemical Compositions of EOs}

The GC-MS analyses of the EOs were carried out by a Clarus 580 GC (PerkinElmer, Waltham, MA, USA) coupled to a Clarus GC/MS SQ (PerkinElmer), in full scan mode (50 to $600 \mathrm{amu}$ ). The identifications of the volatile compounds were obtained matching the mass spectra with the NIST Mass Spectral Library 2.0 (NIST, Gaithersburg, MD, USA) and confirmed by calculating the retention index, as proposed by Lee et al. [22], referred to a series of $n$-hydrocarbons (C8-C40 n-alkanes, Sigma Aldrich), compared with those present in the NIST Chemistry WebBook (http:/ / webbook.nist.gov/chemistry/). The semi-quantitative results were calculated by means of the Turbomass 6.1.0.1963 software (PerkinElmer).

The GC apparatus was equipped with a fused silica Rxi-5ms column $(30 \mathrm{~m} \times 250 \mu \mathrm{m} \times 0.25 \mu \mathrm{m}$ Restek, Milan, Italy). For all the EOs, excepting A. sativum, the oven temperature program started from $45^{\circ} \mathrm{C}$ (holding $10 \mathrm{~min}$ ) and ramped at a rate of $2.5^{\circ} \mathrm{C} / \mathrm{min}$ to $180^{\circ} \mathrm{C}$ (holding $5 \mathrm{~min}$ ); for A. sativum EOs, the oven temperature program started from $50^{\circ} \mathrm{C}$ (holding $1 \mathrm{~min}$ ), ramped at a rate of $5^{\circ} \mathrm{C} / \mathrm{min}$ to 145 ${ }^{\circ} \mathrm{C}$ (holding $15 \mathrm{~min}$ ), ramped at a rate of $7{ }^{\circ} \mathrm{C} / \mathrm{min}$ to $175^{\circ} \mathrm{C}$ and then ramped at a rate of $4{ }^{\circ} \mathrm{C} / \mathrm{min}$ to 
$250{ }^{\circ} \mathrm{C}$ (holding $15 \mathrm{~min}$ ); the carrier gas was helium at flow $1 \mathrm{~mL} / \mathrm{min}$; the injector temperature and the transfer line temperature were set at $250{ }^{\circ} \mathrm{C}$. A $1 \% v / v$ solution of the EOs sample in hexane was prepared and $1 \mu \mathrm{L}$ was injected in a splitless mode.

\subsection{Antioxidant Capacity and Total Phenolic Content}

To assess the antioxidant capacity and total phenolic content, $0.2-2 \mathrm{mg} / \mathrm{mL}$ methanolic solutions of each EO were subjected to the different spectrophotometric assays carried out by a Lambda Bio 20 ultraviolet-visible (UV/vis) spectrophotometer (PerkinElmer). The different assays conditions were presented below.

2.4.1. Trolox Equivalent Antioxidant Capacity with 2,2'-azinobis-(3-ethylbenzothiazoline-6-sulfonic acid (TEAC/ABTS) Assay

The TEAC/ABTS assay was determined as described by Masaldan et al. [23]. The TEAC/ABTS results of the samples were estimated in terms of mmol Trolox equivalent (TE)/g EO as the mean of three replicates.

\subsubsection{Ferric Reducing Antioxidant Power (FRAP) Assay}

The FRAP was determined by using the potassium ferricyanide-ferric chloride method described by Oyaizu [24]. The FRAP of the samples was estimated in terms of $\mathrm{mg}$ Trolox equivalent (TE)/g EO as the mean of three replicates.

\subsubsection{2,2-diphenyl-1-picrylhydrazyl (DPPH) Assay}

The radical-scavenging activity of the EOs methanolic solutions was measured according to the method described by Brand-Williams et al. [25]. The DPPH results were expressed in terms of $\mu \mathrm{g}$ Trolox equivalent (TE)/g EO as the mean of three replicates.

\subsubsection{Total Phenolic Content (TPC)}

TPC was determined by the Folin-Ciocâlteu method described by Lateef Gharib \& Teixeira da Silva [26]. The TPC results were expressed in terms of $\mathrm{mg}$ Gallic acid equivalents (GAE)/g EO as the mean of three replicates.

\subsection{Antimicrobial Activity}

\subsubsection{Microbial Strains and Growth Conditions}

Thirteen strains, listed in Table 1, and belonging to the Faculty of Bioscience and Technology for Food, Agriculture and Environment collection, were employed in the assessment of antimicrobial activity. The strains were stored at $-80^{\circ} \mathrm{C}$ in cryovials, containing anti-freezing agent (glycerol $20 \%$ $v / v$ Sigma) and periodically confirmed by means of plate counts. Before each trial, bacterial strains were cultured overnight in Tryptone Soy agar medium (TSA, Oxoid Thermofisher, Rodano, Italy); after 24-48 h, the cells were inoculated into Tryptone Soy broth (TSB, Oxoid Thermofisher) and incubated to obtain a working fresh culture (early stationary phase). Fresh cultures were collected by centrifugation at $1300 \mathrm{rpm}$ (Eppendorf-Centrifuge 5415D, Hamburg, Germany) for $5 \mathrm{~min}$ and washed for three times

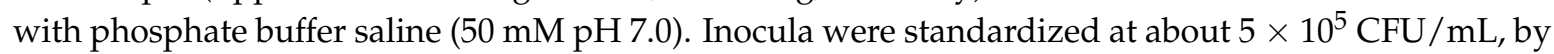
means of Lambda Bio 20 spectrophotometer (PerkinElmer). Strains origin and incubation conditions were also presented in Table 1. 
Table 1. Strains employed for the trial and culture and standardization conditions.

\begin{tabular}{|c|c|c|c|c|}
\hline Strains & & Origin & Incubation Temperature $\left({ }^{\circ} \mathrm{C}\right)$ & Incubation Time (h) \\
\hline Pseudomonas fluorescens & P34 & Dairy products & 28 & 24 \\
\hline Brochothrix thermosphacta & B2 & Poultry meat & 30 & 48 \\
\hline Brochothrix thermosphacta & B1 & Poultry meat & 30 & 48 \\
\hline Salmonella Enteritidis & S2 & Meat & 37 & 24 \\
\hline Salmonella Typhimurium & S4 & Meat & 37 & 24 \\
\hline Enterococcus faecium & P14 & Fish & 30 & 48 \\
\hline Enterococcus faecium & ATCC 19434 & Type strain & 30 & 48 \\
\hline Listeria monocytogenes & LM 4 & Meat products & 37 & 48 \\
\hline Listeria monocytogenes & ATCC 19144 & Type strain & 37 & 48 \\
\hline Listeria monocytogenes & ATCC 7644 & Type strain & 37 & 48 \\
\hline Staphylococcus aureus & STA 32 & Dairy products & 37 & 48 \\
\hline Staphylococcus aureus & STA 47 & Dairy products & 37 & 48 \\
\hline Staphylococcus aureus & STA 39 & Dairy products & 37 & 48 \\
\hline
\end{tabular}

\subsubsection{Determination of Minimal Inhibitory Concentration}

The EOs were investigated for their Minimal Inhibitory Concentration (MIC) values according to the microdilution method, as described by Clinical and Laboratory Standards Institute (CLSI) guidelines [27]. The EOs were dissolved in PBS (Phosphate Buffer Saline) $50 \mathrm{mM} \mathrm{pH} 7.0$ and Tween $80(1 \%)$ to reach the initial concentration of $4.0 \%$; working emulsions were obtained by vortexing for $5 \mathrm{~min}$. The emulsions were sterilized through $0.22 \mu \mathrm{m}$ politetrafluoroetilene (PTFE) Minisart syringe filter (Sartorius, Göttingen, Germany). The inocula were prepared as described in Section 2.5.1. A positive (100 $\mu \mathrm{L}$ of TSB medium and $100 \mu \mathrm{L}$ inoculum) and a negative control (200 $\mu \mathrm{L}$ of sterile TSB medium) were considered for each strain. The lowest EOs concentrations that prevented growth after $48 \mathrm{~h}$ of incubation, was interpreted as the MIC. The Minimum Bactericidal Concentration (MBC) was determined by inoculating the content of wells were no growth was observed, on TSA plates and by incubating the plates at the temperatures reported in Table 1. The MBC was recorded as the lowest concentration not allowing bacterial growth on plates [28].

\subsection{Statistical Analysis}

Experimental results were expressed as means \pm standard deviations. Data obtained were subjected to ANOVA (analysis of variance), and a Tukey's HSD post-hoc test was applied at $p<0.05$, using Microsoft Xlstat 2016 statistical software (Addinsoft, Paris, France). Correlations between TPC and AOC (antioxidant capacity) results and antimicrobial activities, were calculated using Microsoft Xlstat 2016 statistical software (Addinsoft) by means of Pearson Correlation.

\section{Results \& Discussion}

\subsection{Essential Oil Extractions}

The extraction yields were calculated considering the mass $(\mathrm{g})$ of the obtained EOs and the mass $(\mathrm{g})$ of dried material processed. The yield results were expressed as the mean of the three replicates of the extraction \pm standard deviation.

R. officinalis, O. vulgare, S. officinalis, M. piperita, A. sativum, F. vulgare, C. sativum, S. montana, T. vulgaris yields \% were: $0.487 \pm 0.011,2.900 \pm 0.012,0.249 \pm 0.001,1.034 \pm 0.057,0.371 \pm 0.011$, $0.340 \pm 0.016,0.265 \pm 0.010,0.491 \pm 0.027,1.506 \pm 0.096$, respectively. The obtained yields were similar to ranges usually reported in the literature for the same species [26,29-33].

\subsection{Chemical Characterization}

The chemical compositions of the different EOs were reported in Table 2. 
Table 2. Gas Chromatography-Mass Spectrometry (GC-MS) characterization of essential oils (EOs).

\begin{tabular}{|c|c|c|c|c|c|c|c|c|c|c|c|}
\hline ID & RID & RIE & R. officinalis & O. vulgare & S. officinalis & A. sativum & F. vulgare & M. piperita & C. sativum & S. montana & T. vulgaris \\
\hline Diallyl sulfide & 848 & 847 & - & - & - & $0.55 \pm 0.04^{c}$ & - & - & - & - & - \\
\hline Methyl allyl disulfide & 910 & 911 & - & - & - & $0.29 \pm 0.00^{c}$ & - & - & - & - & - \\
\hline$\alpha$-Pinene & 939 & 939 & $16.64 \pm 0.22^{b}$ & $0.47 \pm 0.02^{\mathrm{i}}$ & $1.20 \pm 0.10^{f, g}$ & - & $5.18 \pm 0.73^{c}$ & $0.86 \pm 0.03^{\mathrm{e}}$ & $0.28 \pm 0.00^{\mathrm{e}}$ & - & $0.37 \pm 0.01^{f, g}$ \\
\hline Camphene & 953 & 956 & $3.39 \pm 0.04^{\mathrm{f}}$ & - & $1.38 \pm 0.03^{f}$ & - & - & - & - & - & - \\
\hline Thuja-2,4(10)-diene & 957 & 960 & $0.32 \pm 0.01^{1}$ & - & - & - & - & - & - & - & - \\
\hline 1-Octen-3-ol & 978 & 979 & - & $0.57 \pm 0.02^{\mathrm{h}, \mathrm{i}}$ & - & - & - & - & - & $1.43 \pm 0.02^{\mathrm{e}}$ & - \\
\hline$\beta$-Pinene & 979 & 981 & $2.35 \pm 0.03 \mathrm{~g}$ & - & $2.77 \pm 0.16^{\mathrm{e}}$ & - & $1.03 \pm 0.05^{\mathrm{e}}$ & $0.52 \pm 0.01 \mathrm{e}$ & - & - & $1.87 \pm 0.09^{\mathrm{f}}$ \\
\hline$\beta$-Myrcene & 992 & 993 & $0.72 \pm 0.01 \mathrm{k}$ & - & - & - & $0.65 \pm 0.06^{\mathrm{e}}$ & - & $0.28 \pm 0.03^{\mathrm{e}}$ & $0.55 \pm 0.03^{\mathrm{e}}$ & $0.56 \pm 0.02 \mathrm{~g}, \mathrm{~h}$ \\
\hline$\alpha$-Phellandrene & 1005 & 1006 & - & - & - & - & $10.49 \pm 0.02^{b}$ & - & - & - & - \\
\hline trans- $\beta$-Ocimene & 1015 & 1014 & $0.38 \pm 0.02^{1}$ & - & - & - & - & - & - & - & - \\
\hline$p$-Cymene & 1024 & 1021 & $1.75 \pm 0.01^{\mathrm{i}}$ & $8.30 \pm 0.02^{c}$ & $0.52 \pm 0.03 \mathrm{~g}$ & - & $3.33 \pm 0.24^{\mathrm{d}}$ & - & $0.31 \pm 0.00^{\mathrm{e}}$ & $10.78 \pm 0.41^{\mathrm{b}}$ & $18.57 \pm 0.71^{b}$ \\
\hline Limonene & 1029 & 1029 & - & - & & - & $4.56 \pm 0.38^{\mathrm{c}, \mathrm{d}}$ & - & $0.33 \pm 0.00^{\mathrm{e}}$ & $0.69 \pm 0.04 \mathrm{e}$ & - \\
\hline 1,8-Cineole & 1032 & 1034 & $15.71 \pm 0.18^{c}$ & - & $10.02 \pm 0.36^{\mathrm{c}}$ & - & - & $5.35 \pm 0.38^{\mathrm{c}, \mathrm{d}}$ & - & $0.53 \pm 0.01^{\mathrm{e}}$ & - \\
\hline$\gamma$-Terpinene & 1060 & 1061 & $0.46 \pm 0.02^{\mathrm{k}, \mathrm{l}}$ & $9.38 \pm 0.01^{c}$ & - & - & - & - & $1.19 \pm 0.07^{\mathrm{d}, \mathrm{e}}$ & $6.46 \pm 0.71^{c}$ & $4.92 \pm 0.13^{c, d}$ \\
\hline cis-Sabinene hydrate & 1066 & 1064 & - & - & - & - & - & - & - & - & $3.17 \pm 0.03^{\mathrm{e}}$ \\
\hline Diallyl disulfide & 1080 & 1079 & - & - & - & $20.16 \pm 2.84^{b}$ & - & - & - & - & - \\
\hline Terpinolene & 1087 & 1085 & - & - & - & - & - & - & - & - & $4.54 \pm 0.06^{\mathrm{d}}$ \\
\hline Fenchone & 1088 & 1088 & - & - & - & - & $10.12 \pm 0.07^{b}$ & - & - & - & - \\
\hline (S)-(+)-Linalool & 1100 & 1099 & $2.02 \pm 0.01^{\mathrm{h}}$ & $1.95 \pm 0.10^{\mathrm{e}, \mathrm{f}}$ & - & - & - & $0.86 \pm 0.04{ }^{\mathrm{e}}$ & $77.07 \pm 1.82^{\mathrm{a}}$ & $2.09 \pm 0.10^{\mathrm{d}, \mathrm{e}}$ & $0.37 \pm 0.01 \mathrm{~g}, \mathrm{~h}$ \\
\hline$\alpha$-Thujone & 1102 & 1104 & & & $30.46 \pm 0.49^{a}$ & & & & & & \\
\hline 1-Octen-3-ol, acetate & 1110 & 1113 & - & - & - & - & - & - & - & - & $1.27 \pm 0.01^{\mathrm{f}, \mathrm{g}}$ \\
\hline Menthone & 1126 & 1116 & - & - & - & - & - & $6.87 \pm 0.11^{b, c}$ & - & - & - \\
\hline L-Pinocarveol & 1135 & 1132 & $0.23 \pm 0.01^{1}$ & - & - & - & - & - & - & - & - \\
\hline Camphor & 1139 & 1137 & $22.07 \pm 0.23^{a}$ & - & $11.53 \pm 0.34^{\mathrm{b}}$ & - & - & - & $2.60 \pm 0.10^{c, d}$ & - & $0.29 \pm 0.02^{h}$ \\
\hline Borneol & 1162 & 1160 & $11.99 \pm 0.04^{\mathrm{d}}$ & $0.66 \pm 0.01 \mathrm{~g}, \mathrm{~h}, \mathrm{i}$ & $3.92 \pm 0.02^{\mathrm{d}}$ & - & - & - & $0.48 \pm 0.01^{\mathrm{e}}$ & $4.51 \pm 0.37^{\mathrm{c}, \mathrm{d}}$ & - \\
\hline Menthofuran & 1164 & 1165 & - & - & - & - & - & $7.81 \pm 0.59^{b}$ & - & - & - \\
\hline Menthol & 1171 & 1178 & - & - & - & - & - & $53.39 \pm 0.24^{\mathrm{a}}$ & - & - & - \\
\hline Isocamphopinone & 1175 & 1174 & $1.08 \pm 0.00^{j}$ & - & - & - & - & - & - & - & - \\
\hline Terpinene-4-ol & 1179 & 1176 & $0.26 \pm 0.01^{1}$ & $0.38 \pm 0.01^{\mathrm{i}}$ & $1.43 \pm 0.09^{\mathrm{f}}$ & - & - & - & $0.55 \pm 0.03^{\mathrm{e}}$ & - & - \\
\hline 2-Vinyl-1.3-dithiane & 1182 & 1084 & - & - & - & $4.60 \pm 0.09^{c}$ & - & - & - & - & - \\
\hline Isomenthol & 1194 & 1192 & - & - & - & - & - & - & - & - & - \\
\hline$\alpha$-Terpineol & 1195 & 1195 & $1.49 \pm 0.08^{\mathrm{i}}$ & $1.64 \pm 0.04^{\mathrm{f}, \mathrm{g}, \mathrm{h}, \mathrm{i}}$ & $0.51 \pm 0.01 \mathrm{~g}$ & - & $0.49 \pm 0.03^{\mathrm{e}}$ & - & $0.59 \pm 0.03^{\mathrm{e}}$ & $1.61 \pm 0.02^{\mathrm{e}}$ & $4.48 \pm 0.09^{\mathrm{d}}$ \\
\hline Myrtenol & 1196 & 1194 & $2.35 \pm 0.03 \mathrm{~g}$ & - & - & - & - & - & - & - & $2.82 \pm 0.15^{\mathrm{e}}$ \\
\hline Estragole & 1199 & 1198 & - & - & - & - & $44.86 \pm 0.26^{\mathrm{a}}$ & & - & - & - \\
\hline Verbenone & 1205 & 1203 & $0.44 \pm 0.05^{1}$ & - & - & - & - & - & - & - & - \\
\hline Isopulegone & 1237 & 1237 & - & - & - & - & - & $2.01 \pm 0.03^{\mathrm{e}}$ & - & - & - \\
\hline Piperitone & 1253 & 1250 & - & - & - & - & - & $0.21 \pm 0.02^{\mathrm{e}}$ & - & - & - \\
\hline cis-Geraniol & 1254 & 1256 & - & - & - & - & - & - & $5.24 \pm 0.39^{b}$ & - & - \\
\hline Thymol methyl ether & 1255 & 1257 & - & $1.04 \pm 0.01^{\mathrm{f}, \mathrm{g}, \mathrm{h}}$ & - & - & - & - & - & - & - \\
\hline Neomenthyl acetate & 1273 & 1270 & - & - & - & - & - & $0.81 \pm 0.06^{\mathrm{e}}$ & - & - & - \\
\hline trans-anethol & 1285 & 1282 & & - & - & - & $6.55 \pm 0.06^{\mathrm{c}}$ & - & - & - & - \\
\hline
\end{tabular}


Table 2. Cont.

\begin{tabular}{|c|c|c|c|c|c|c|c|c|c|c|c|}
\hline ID & RID & RIE & R. officinalis & O. vulgare & S. officinalis & A. sativum & F. vulgare & M. piperita & C. sativum & S. montana & T. vulgaris \\
\hline Bornyl acetate & 1286 & 1286 & $5.62 \pm 0.011^{\mathrm{e}}$ & - & - & - & - & - & - & - & - \\
\hline Thymol & 1290 & 1290 & - & $40.32 \pm 1.12^{\mathrm{a}}$ & - & - & - & - & - & $2.53 \pm 0.14^{\mathrm{d}, \mathrm{e}}$ & $43.68 \pm 0.54^{\mathrm{a}}$ \\
\hline Menthyl acetate & 1295 & 1294 & - & - & - & - & - & $4.61 \pm 0.01^{\mathrm{d}}$ & - & - & - \\
\hline Carvacrol & 1299 & 1299 & - & $16.20 \pm 0.05^{b}$ & - & - & $0.63 \pm 0.01^{\mathrm{e}}$ & - & $1.03 \pm 0.03^{\mathrm{d}, \mathrm{e}}$ & $54.17 \pm 2.33^{\mathrm{a}}$ & $5.51 \pm 0.12^{c}$ \\
\hline Diallyl trisulfide & 1301 & 1300 & - & - & - & $65.39 \pm 2.50^{\mathrm{a}}$ & - & - & - & - & - \\
\hline Isocaryophyllene & 1438 & 1434 & $3.37 \pm 0.20^{\mathrm{f}}$ & $2.90 \pm 0.07^{\mathrm{e}}$ & $10.49 \pm 0.00^{c}$ & - & $1.05 \pm 0.05^{\mathrm{e}}$ & $1.67 \pm 0.03^{\mathrm{e}}$ & $0.62 \pm 0.02^{\mathrm{e}}$ & $2.91 \pm 0.11^{\mathrm{d}, \mathrm{e}}$ & $1.61 \pm 0.03^{f}$ \\
\hline Humulene & 1467 & 1467 & $0.72 \pm 0.02^{\mathrm{k}}$ & $0.77 \pm 0.03 \mathrm{~g}, \mathrm{~h}, \mathrm{i}$ & $10.01 \pm 0.35^{\mathrm{c}}$ & - & $0.49 \pm 0.01^{\mathrm{e}}$ & - & - & - & - \\
\hline Germacrene-D & 1487 & 1490 & - & $0.90 \pm 0.01^{\mathrm{f}, \mathrm{g}, \mathrm{h}, \mathrm{i}}$ & - & - & - & $0.87 \pm 0.02^{\mathrm{e}}$ & - & - & $0.55 \pm 0.01^{\mathrm{g}, \mathrm{h}}$ \\
\hline$\beta$-Bisabolene & 1506 & 1509 & - & $4.64 \pm 0.06^{\mathrm{d}}$ & - & - & - & - & $0.83 \pm 0.04^{\mathrm{d}, \mathrm{e}}$ & $1.82 \pm 0.03^{\mathrm{e}}$ & $1.64 \pm 0.01^{\mathrm{f}}$ \\
\hline$\gamma$-Cadinene & 1513 & 1514 & - & - & - & - & - & - & - & $0.54 \pm 0.02^{\mathrm{e}}$ & - \\
\hline$\delta$-Cadinene & 1523 & 1522 & - & $0.65 \pm 0.01^{\mathrm{g}, \mathrm{h}, \mathrm{i}}$ & $0.45 \pm 0.01 \mathrm{~g}$ & - & - & - & - & $0.54 \pm 0.02 \mathrm{e}$ & - \\
\hline Diallyl tetrasulfide & 1555 & 1557 & - & - & - & $1.49 \pm 0.07^{c}$ & - & - & - & - & - \\
\hline Caryophyllene oxide & 1581 & 1583 & - & $1.73 \pm 0.01^{f, g}$ & $1.92 \pm 0.05^{e, f}$ & - & - & $1.21 \pm 0.04^{\mathrm{e}}$ & $3.16 \pm 0.17^{c}$ & $1.41 \pm 0.05^{\mathrm{e}}$ & - \\
\hline Ledene & 1585 & 1589 & - & - & $10.12 \pm 0.44^{\mathrm{c}}$ & - & - & - & - & - & - \\
\hline Total identified & poun & & $93.35 \pm 0.43$ & $92.52 \pm 0.84$ & $97.04 \pm 0.46$ & $92.47 \pm 0.39$ & $90.44 \pm 0.87$ & $93.17 \pm 0.39$ & $94.55 \pm 1.69$ & $92.56 \pm 3.94$ & $96.22 \pm 1.47$ \\
\hline
\end{tabular}

Results were expressed as mean relative abundances \% of three replicates. In the table: ID, component name; RID, retention index retrieved from http:/ / webbook.nist.gov/ chemistry/ for the same analysis conditions; RIE, experimental retention index referred to $C 8-C 40 n$-alkane mixture standard. Statistical groups were defined by progressive alphabetical letters (case-letter). For the same matrix (same column), results followed by the same case-letter are not significantly different according to Tukey' HSD post hoc test $(p>0.05$ ). 
Regarding R. officinalis EO, the components identified were in accordance with those reported by other authors [34-36] for this officinal plant. The major components $(p<0.05)$ of the mixture were camphor $(22 \%), \alpha$-pinene (17\%), 1,8-cineole (16\%) and borneol (12\%). These approximately equal ratios have been already recognized to be characteristic of some $R$. officinalis species from Italy and nearby countries [15,37]; however, 1,8-cineole chemotype is generally reported for rosemary plants cultivated in different other locations of Italy $[35,37,38]$.

For O. vulgare EO, the major constituent $(p<0.05)$ was thymol $(40 \%)$, followed by carvacrol $(16 \%), \gamma$-terpinene $(9 \%)$ and $p$-cymene $(8 \%)$. The obtained data were similar with those reported by De Martino et al. [39] for thymol/carvacrol chemotypes cultivated in a southern region of Italy, by Vazirian et al. [40] and Daferera et al. [41] for Iranian and Greek oregano EOs, respectively. The main compound of $O$. vulgare EO is usually carvacrol or thymol, while other authors stated that camphor was the main constituent $[15,42,43]$.

S. officinalis EO showed $\alpha$-tujone (41\%) as main constituent $(p<0.05)$, followed by camphor $(12 \%)$ and equal ratios $(p>0.05)$ of 1,8-cineole/isocaryophyllene/humulene/ledene (total abundance of $42 \%$ ). The chemical composition was in accordance with those reported in literature by different authors for some European and Iranian sages [44,45], anyhow in these works lower concentrations of $\alpha$-tujone were recorded.

For A. sativum EO a total of six compounds were identified. The principal component $(p<0.05)$ was diallyl disulfide $(65 \%)$, followed by diallyl trisulfide $(20 \%)$, in accordance with the results reported by Dziri et al. [46]. These compounds represent two of the main compounds produced during the thermal or long-term decomposition of allicin, the unstable garlic main constituent released from the alliin upon an injury and by means of the activity of the enzyme alliinase [47].

T. vulgaris EO presented thymol $(44 \%)$ as major compound $(p<0.05)$, thus in our case the thyme chemotype was thymol. In scientific literature there are contrasting data about the area cultivation-related chemotype, being T. vulgaris characterized by an evident chemotype variation that lead to different monoterpene co-occurrence and composition [48].

Regarding F. vulgare EO, the major component $(p<0.05)$ was estragole $(45 \%)$, followed by similar values $(p>0.05)$ of fenchone (10\%) and $\alpha$-phellandrene $(10 \%)$. For M. piperita, menthol (53\%) was the EO main compound $(p<0.05)$, followed by menthofuran $(8 \%)$ and menthone $(7 \%)$. (S)-(+)-Linalool was the principal constituent $(p<0.05)$ of $C$. sativum EO obtained from plant seeds, for which a $77 \%$ of the total volatile mixture was accountable. In S. montana EO, carvacrol was the compound with the highest $(p<0.05)$ relative abundance $(54 \%)$. For these last four EOs, the obtained data were in accordance with those reported in the literature from other authors [49-54].

The GC-MS chemical characterization of the analyzed samples allowed to identify the main components of the extracted EOs (total identified compounds $>90 \%$ ); in addition, the data comparison with scientific literature underlined the influence of the environmental conditions of plant cultures on the composition of their volatile fraction.

\subsection{Total Phenolic Content and Antioxidant Activity}

Total phenolic content (TPC) results were showed in Table 3. The highest TPC $(p<0.05)$ was recorded for T. vulgaris EO (6.42 $\mathrm{mg} \mathrm{GAE/g} \mathrm{EO),} \mathrm{followed} \mathrm{by} \mathrm{O.} \mathrm{vulgare} \mathrm{(4.69} \mathrm{mg} \mathrm{GAE/g} \mathrm{EO)} \mathrm{and}$ S. montana (4.40 mg GAE/g EO). The other EOs showed lower values $(p<0.05)$ with a TPC range of $0.05-0.28 \mathrm{mg} \mathrm{GAE} / \mathrm{g}$ EO and no significant differences among them $(p>0.05)$. 
Table 3. Total phenolic content (TPC) and antioxidant activity results Ferric Reducing Antioxidant Power (FRAP), 2,2-diphenyl-1-picrylhydrazyl (DPPH) and Trolox Equivalent Antioxidant Capacity with 2,2'-azinobis-(3-ethylbenzothiazoline-6-sulfonic acid (TEAC/ABTS) of EOs and Pearson correlation coefficients between the different antioxidant activity assays and total phenolic content.

\begin{tabular}{|c|c|c|c|c|}
\hline Assay & TPC & FRAP & DPPH & ABTS \\
\hline Rosmarinus officinalis & $0.111 \pm 0.002^{c}$ & $188.270 \pm 0.437^{\mathrm{a}}$ & $10.288 \pm 0.258^{c, d}$ & $0.084 \pm 0.001$ \\
\hline Origanum vulgare & $4.688 \pm 0.304^{b}$ & $168.220 \pm 1.837^{b}$ & $23.963 \pm 2.435^{b}$ & $1.765 \pm 0.005^{b}$ \\
\hline Salvia officinalis & $0.178 \pm 0.008^{c}$ & $12.304 \pm 0.022^{f}$ & $8.709 \pm 0.885^{c, d}$ & $0.098 \pm 0.005^{\mathrm{e}}$ \\
\hline Mentha piperita & $0.338 \pm 0.018^{c}$ & $0.543 \pm 0.044^{\mathrm{h}}$ & $11.289 \pm 0.514^{c}$ & $0.154 \pm 0.006^{\mathrm{d}}$ \\
\hline Allium sativum & $0.050 \pm 0.001^{c}$ & $3.924 \pm 0.142 \mathrm{~g}$ & $7.868 \pm 0.158^{\mathrm{d}}$ & $0.037 \pm 0.003$ \\
\hline Foeniculum vulgare & $0.283 \pm 0.013^{c}$ & $15.202 \pm 0.175^{\mathrm{e}}$ & $11.466 \pm 0.636^{c}$ & $0.043 \pm 0.003$ \\
\hline Coriandrum sativum & $0.046 \pm 0.004^{c}$ & $4.122 \pm 0.241^{g}$ & $10.656 \pm 1.043^{\mathrm{c}, \mathrm{d}}$ & $0.067 \pm 0.004^{f}$ \\
\hline Satureja montana & $4.398 \pm 0.252^{b}$ & $159.280 \pm 1.575^{\mathrm{c}}$ & $27.015 \pm 0.959^{\mathrm{a}}$ & $1.997 \pm 0.003^{\circ}$ \\
\hline Thymus vulgaris & $6.419 \pm 0.219^{a}$ & $126.869 \pm 0.175^{d}$ & $21.751 \pm 0.862^{b}$ & $1.131 \pm 0.012$ \\
\hline \multicolumn{5}{|c|}{ Pearson Correlation Coefficients } \\
\hline Assay & FRAP & ABT & & DPPH \\
\hline TPC & 0.642 & 0.69 & & 0.905 \\
\hline
\end{tabular}

Regarding TPC and AOC (antioxidant activity): results were expressed as mg Gallic acid equivalents (GAE)/g EO for TPC assay; mg Trolox equivalent (TE)/g EO for FRAP assay; $\mu \mathrm{g}$ Trolox equivalent (TE)/g EO for DPPH assay; mmol Trolox equivalent/g EO for ABTS assay. The showed values were the mean of three replicates. For the same assay (same column), results followed by the same case-letter are not significantly different according to Tukey' HSD post hoc test $(p>0.05)$. For Pearson Correlation Coefficients: the positive/negative strength of correlation was considered: low for $\pm 0.1<r< \pm 0.3$, moderate for $\pm 0.3<r< \pm 0.7$, and strong for $r> \pm 0.7$; for values of $r< \pm 0.1$ the variables were considered not correlated.

Antioxidant activity (FRAP, DPPH, TEAC/ABTS) results were also reported in Table 3. The different assays established that $O$. vulgare, S. montana and T. vulgaris were the EOs with the best antioxidant capacity according to free radical scavenging methods (DPPH and TEAC/ABTS). The FRAP assay underlined also the antioxidant potential of $R$. officinalis EO.

Even if the vegetal matrix had different origins, the methodology of the investigation and expression of results made difficult a direct comparison between TPC and AOC data and the literature. The presented ranges were similar to those presented by several authors for different essential oils $[15,20,26,43,55]$.

A Pearson correlation test between the AOC and TPC data was carried out and the coefficients results obtained were presented in Table 3. As reported, among the different assays, a moderate (TPC with FRAP and ABTS) and strong (TPC with DPPH) positive correlation were revealed. Thus, the detected antioxidant activity could be attributed to total phenols content assessed in the EOs. These positive correlations between AOC and TPC have been already reported for plant species of the Mediterranean area [56].

\subsection{Antimicrobial Activity}

The antibacterial activity of the tested EOs against selected Gram-positive and Gram-negative bacteria was reported in Table 4. The strains were selected among spoiling (P. fluorescens, B. thermosphacta and E. faecium) and pathogenic (Salmonella enterica serotype Enteritidis and Salmonella enterica serotype Typhimurium, L. monocytogenes and S. aureus) bacteria commonly isolated from food products of different origins, to have an overview of the potentiality of the selected essential oils.

Generally, the results observed as MIC were also confirmed as MBC. In some cases, the MIC concentration had to be doubled to obtain a bactericidal activity (i.e., MBC of T. vulgaris and C. sativum EOs was respectively 5 and $10 \mu \mathrm{L} / \mathrm{mL}$ for both $B$. thermosphacta B1 and B2).

For F. vulgare EO, the results established that the obtained $\mathrm{EO}$ was unable to inhibit the tested microbial strains at concentrations lower or equal than $20 \mu \mathrm{L} / \mathrm{mL}$. The results were in accordance with those reported by Çetin et al. [57], who assessed that for fennel EOs obtained from the aerial parts, as in our case, the different MIC values ranged from 31.25 to $500 \mu \mathrm{g} / \mathrm{mL}$. Lower MIC values could 
be obtained from EOs extracted from seeds [42,58] and fruits [59] of the plant; in these cases, the EOs main compound is trans-anethol, present only in minor quantities in our EO.

Regarding R. officinalis, S. officinalis, M. piperita and A. sativum, the EO tested showed a limited spectrum of activity; good results $(5 \mu \mathrm{L} / \mathrm{mL})$ were obtained against different strains, however higher MIC values obtained for the other strains belonging to the same species seemed to underline a strain-dependent activity. Thus, for these EOs, a variable antimicrobial activity against the Gram-negative and Gram-positive bacteria tested, was generally recognized at concentrations higher than $10 \mu \mathrm{L} / \mathrm{mL}$. Nevertheless, significant results were observed for A. sativum EO against the two Listeria monocytogenes type strains. Good results were also obtained for R. officinalis EO; in fact, it usually shows a good antioxidant activity [60] and a lower antimicrobial activity with respect to other EOs such as oregano, thyme or tea tree [43], while in our case it showed good inhibitory activity, particularly on L. monocytogenes ATCC7644 and S. aureus STA47. This activity is probably due to the presence of camphor and 1,8-cineol among the principal constituents, as reported in Table 2.

For O. vulgare, the MIC values showed a wide spectrum of activity, ranging from 1.25 to $10 \mu \mathrm{L} / \mathrm{mL}$ for both Gram-positive and Gram-negative bacteria. In this case, the antimicrobial activity could be related to the important presence of thymol and carvacrol in the volatile fraction, as described in Section 3.1 (Table 2); the high contents of thymol, in fact, results in good antimicrobial activities [39,61].

The most effective EOs were those obtained from S. montana, T. vulgaris and C. sativum. For these EOs the MIC values ranged from 0.625 to $5 \mu \mathrm{L} / \mathrm{mL}$. For these EOs thymol, (S)-(+)-linalool, and carvacrol have been already confirmed to be responsible for their antimicrobial activity, with ranges similar to those obtained in the present study [43,62-64]. In particular, while the antimicrobial activity of O. vulgare and T. vulgaris EOs against L. monocytogenes is well known $[65,66]$, very interesting results were observed for $C$ sativum against Listeria, but also the other tested pathogens, such as S. aureus (especially strain STA32) and Salmonella strains. These results are particularly significant, as Gram-negative bacteria are usually less sensitive to EOs than Gram-positive, because of the presence of the lipopolysaccharide layer, that provides a higher resistance to hydrophobic compounds such as essential oils [67]. On the contrary, the Gram-positive B. thermosphacta strains B1 and B2 were among the most resistant strains, nevertheless, they were inhibited by low concentrations of T. vulgaris and S. montana EOs. 
Table 4. Minimum Inhibitory Concentration $(\mathrm{MIC})(\mu \mathrm{L} / \mathrm{mL})$ of selected essential oils against the different strains.

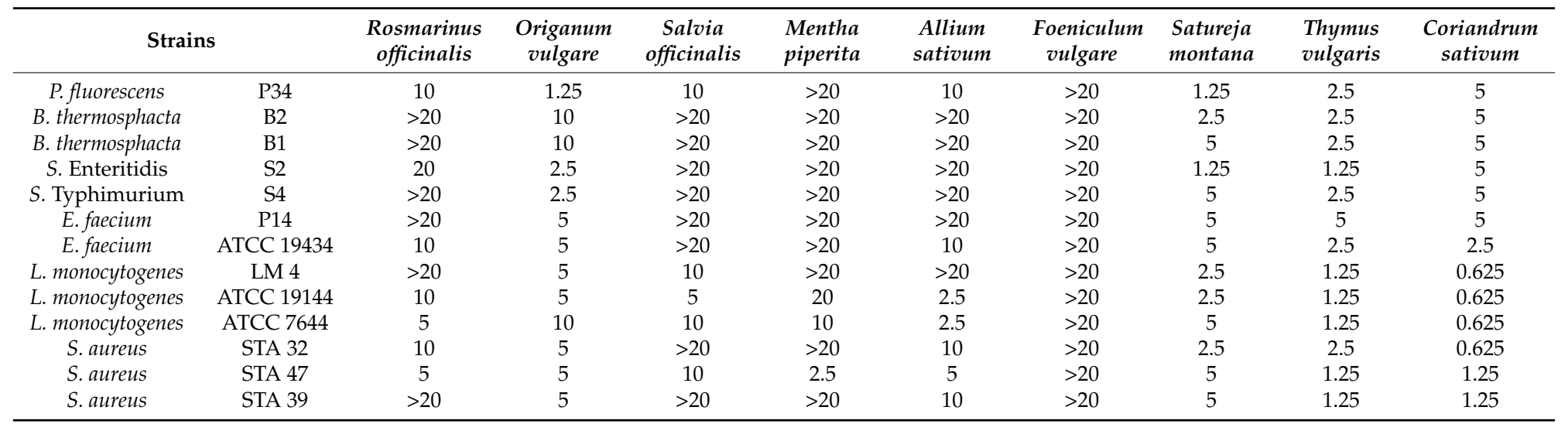




\section{Conclusions}

The results obtained from this study established that the essential oils obtained from Abruzzo region officinal plants, mainly from T. vulgaris, S. montana and C. sativum, showed interesting biological potentiality. The antimicrobial and antioxidant properties assessed are excellent bases for further in vitro assays that could be used to define these essential oils as potential candidates for natural biopreservatives in combination with or in substitution to synthetic chemical ones. Moreover, additional studies should be undertaken in order to understand their potentiality in model systems and in real food samples. Study should particularly aim to establish the most effective EO concentration depending on the food matrix, its organoleptic properties, and the microorganisms it should inhibit. Anyhow, these results represent a valid basis for future evaluations and enriched current understanding about the specificity of Abruzzo region plant species and their essential oils.

Acknowledgments: This research was supported by the grant of Regione Abruzzo, for the project "PSR 2017-2013 Misura 1.2.4" cod. CUA 2446850691, title "Sviluppo di sistemi convenzionali e innovazioni per la produzione di composti bioattivi da materie prime vegetali per l'impiego nel settore alimentare".

Author Contributions: Claudio Lo Sterzo and Antonello Paparella conceived and designed the experiments; Marika Pellegrini, Giovanni Mazzarrino and Serena D'Amato performed the experiments; Marika Pellegrini, Antonella Ricci, Annalisa Serio and Clemencia Chaves-López analyzed the data and wrote the paper.

Conflicts of Interest: Authors declare no conflict of interest.

\section{References}

1. Blackburn, C. Introduction. In Food Spoilage Microorganisms, 1st ed.; Blackburn, C., Ed.; Woodhead Publishing Ltd.: Cambridge, UK, 2006; pp. xvii-xxiii, ISBN 9781845691417.

2. Hyldgaard, M.; Mygind, T.; Meyer, R.L.; Debabov, D. Essential oils in food preservation: Mode of action, synergies, and interactions with food matrix components. Front. Microbiol. 2012, 3, 1-24. [CrossRef] [PubMed]

3. Oussalah, M.; Caillet, S.; Saucier, L.; Lacroix, M. Inhibitory effects of selected plant essential oils on the growth of four pathogenic bacteria: E. coli O157:H7, Salmonella Typhimurium, Staphylococcus aureus and Listeria monocytogenes. Food Control 2007, 18, 414-420. [CrossRef]

4. Tserennadmid, R.; Takó, M.; Galgóczy, L.; Papp, T.; Pesti, M.; Vágvölgyi, C.; Almássy, K.; Krisch, J. Anti yeast activities of some essential oils in growth medium, fruit juices and milk. Int. J. Food Microbiol. 2011, 144, 480-486. [CrossRef] [PubMed]

5. Tsai, M.L.; Lin, C.C.; Lin, W.C.; Yang, C.H. Antimicrobial, Antioxidant, and Anti-Inflammatory Activities of Essential Oils from Five Selected Herbs. Biosci. Biotechnol. Biochem. 2014, 75, 1977-1983. [CrossRef]

6. Swamy, M.K.; Akhtar, M.S.; Sinniah, U.R. Antimicrobial Properties of Plant Essential Oils against Human Pathogens and Their Mode of Action: An Updated Review. eCAM 2016, 2016. [CrossRef] [PubMed]

7. Grassmann, J. Terpenoids as Plant Antioxidants. Vitam. Horm. 2005, 72, 505-535. [PubMed]

8. Martins, N.; Barros, L.; Ferreira, I.C.F.R. In vivo antioxidant activity of phenolic compounds: Facts and gaps. Trends Food Sci. Technol. 2016, 48, 1-12. [CrossRef]

9. Muthupandi, M.A.; Rajagopal, S.S. Phytochemical Evaluation and in vitro Antioxidant Activity of Various Solvent Extracts of Leucas aspera (Willd.) Link Leaves. Free Radic. Antioxid. 2017, 7, 166-171.

10. Council of Europe. European Pharmacopoeia, 3rd ed.; Council of Europe: Strasbourg, France, 1997; ISBN 9287129916.

11. Sefidkon, F. Influence of drying and extraction methods on yield and chemical composition of the essential oil of Satureja hortensis. Food Chem. 2006, 99, 19-23. [CrossRef]

12. Şanli, A.; Karadoğan, T. Geographical Impact on Essential Oil Composition of Endemic Kundmannia anatolica Hub.-Mor. (Apiaceae). Afr. J. Tradit. Complement. Altern. Med. 2016, 14, 131-137.

13. Silveri, A.; Manzi, A. Horticultural biodiversity and gardening in the region of Abruzzo. In Crop Genetic Resources in European Home Gardens, Proceedings of a Workshop, Ljubljana, Slovenia, 3-4 October 2007; Bailey, A., Eyzaguirre, P., Maggioni, L., Eds.; Bioversity International: Rome, Italy, 2009; pp. 26-36.

14. Guarrera, P.M. Food medicine and minor nourishment in the folk traditions of Central Italy (Marche, Abruzzo ans Latium). Fitoterapia 2003, 74, 515-544. [CrossRef] 
15. Viuda-Martos, M.; Ruiz Navajas, Y.; Sánchez Zapata, E.; Fernández-lópez, J.; Pérez-álvarez, J.A. Antioxidant activity of essential oils of five spice plants widely used in a Mediterranean diet. Flavour Frag. J. 2009, 25, 13-19. [CrossRef]

16. Hadjichambis, A.C.H.; Paraskeva-Hadjichambi, D.; Della, A.; Giusti, M.E.; De Pasquale, C.; Lenzarini, C.; Censorii, E.; Gonzales-Tejero, M.R.; Sanchez-Rojas, C.P.; Ramiro-Gutierrez, J.M.; et al. Wild and semi-domesticated food plant consumption in seven circum-Mediterranean areas. Int. J. Food Sci. Nutr. 2008, 59, 383-414. [CrossRef] [PubMed]

17. Carrubba, A.; Scalenghe, R. The scent of Mare Nostrum: Medicinal and aromatic plants in Mediterranean soils. J. Sci. Food Agric. 2012, 92, 1150-1170. [CrossRef] [PubMed]

18. Lai, P.K.; Roy, J. Antimicrobial and Chemopreventive Properties of Herbs and Spices. Curr. Med. Chem. 2004, 11, 1451-1460. [CrossRef] [PubMed]

19. Tajkarimi, M.M.; Ibrahim, S.A.; Cliver, D.O. Antimicrobial herb and spice compounds in food. Food Control 2010, 21, 1199-1218. [CrossRef]

20. Yashin, A.; Yashin, Y.; Xia, X.; Nemzer, B. Antioxidant Activity of Spices and Their Impact on Human Health: A Review. Antioxidants 2017, 6, 70. [CrossRef] [PubMed]

21. Sajid Arshad, M.; Ayesha Batool, S. Natural Antimicrobials, their Sources and Food Safety. In Food Additives; Karunaratne, D.N., Pamunuwa, G., Eds.; InTech: Rijeka, Croatia, 2017; pp. 87-102.

22. Lee, L.M.; Vassilaros, D.L.; White, C.M. Retention indices for programmed-temperature capillary-column gas chromatography of polycyclic aromatic hydrocarbons. Anal. Chem. 1979, 51, 768-773. [CrossRef]

23. Masaldan, S.; Iyer, V.V. Antioxidant and antiproliferative activities of methanolic extract of Aloe vera leaves in human cancer cell lines. J. Pharm. Res. 2011, 4, 2791-2796.

24. Oyaizu, M. Studies on products of browning reaction: Antioxidative activity of products of browning reaction prepared from glucosamine. Japan. J. Nutr. 1986, 44, 307-315. [CrossRef]

25. Brand-Williams, W.; Cuvelier, M.E.; Berset, C. Use of a free radical method to evaluate antioxidant activity. LWT Food Sci. Technol. 1995, 28, 25-30. [CrossRef]

26. El-Lateef Gharib, F.A.; Teixeira da Silva, J.A. Composition, Total Phenolic Content and Antioxidant Activity of the Essential Oil of Four Lamiaceae Herbs. Med. Aromat. Plant Sci. Biotechnol. 2013, 7, 19-27.

27. Clinical and Laboratory Standards Institute. Performance Standards for Antimicrobial Susceptibility Testing; Twenty-First Informational Supplement; M100-S21; CLSI: Wayne, MI, USA, 2011.

28. Rossi, C.; Chaves-López, C.; Serio, A.; Annibali, F.; Valbonetti, L.; Paparella, A. Effect of Origanum vulgare Essential Oil on Biofilm Formation and Motility Capacity of Pseudomonas fluorescens Strains Isolated from Discolored Mozzarella Cheese. J. Appl. Microbiol. 2018. Accepted. [CrossRef] [PubMed]

29. Panizzi, L.; Flamini, G.; Cioni, P.L.; Morelli, I. Composition and Antimicrobial Properties of Essential Oils of 4 Mediterranean Lamiaceae. J. Ethnopharmacol. 1993, 39, 167-170. [CrossRef]

30. Burdock, G.A.; Carabin, J.G. Safety assessment of coriander (Coriandrum sativum L.) essential oil as a food ingredient. Food Chem. Toxicol. 2009, 47, 22-34. [CrossRef] [PubMed]

31. Russo, M.; Galletti, G.C.; Bocchini, P.; Carnacini, A. Essential Oil Chemical Composition of Wild Populations of Italian Oregano Spice (Origanum vulgare ssp. hirtum (Link) Ietswaart): A Preliminary Evaluation of Their Use in Chemotaxonomy by Cluster Analysis. 1. Inflorescences. J. Food Chem. 1998, 8561, 3741-3746. [CrossRef]

32. Sowbhagya, H.B.; Purnima, K.T.; Florence, S.P.; Rao, A.G.A.; Srinivas, P. Evaluation of enzyme-assisted extraction on quality of garlic volatile oil. Food Chem. 2009, 113, 1234-1238. [CrossRef]

33. Piccaglia, R.; Marotti, M. Characterization of several aromatic plants grown in northern Italy. Flavour Fragr. J. 1993, 8, 115-122. [CrossRef]

34. Yesil Celiktas, O.; Hames Kocabas, E.E.; Bedir, E.; Vardar Sukan, F.; Ozek, T.; Baser, K.H.C. Antimicrobial activities of methanol extracts and essential oils of Rosmarinus officinalis, depending on location and seasonal variations. Food Chem. 2007, 100, 553-559. [CrossRef]

35. Angioni, A.; Barra, A.; Cereti, E.; Barile, D.; Coïsson, J.D.; Arlorio, M.; Dessi, S.; Coroneo, V.; Cabras, P. Chemical Composition, Plant Genetic Differences, Antimicrobial and Antifungal Activity Investigation of the Essential Oil of Rosmarinus officinalis L. J. Agric. Food Chem. 2004, 52, 3530-3535. [CrossRef] [PubMed] 
36. Takayama, C.; Meira de-Faria, F.; Alves de Almeida, A.C.; Dunder, R.J.; Manzo, L.P.; Rabelo Socca, E.A.; Batista, L.M.; Salvador, M.J.; Monteiro Souza-Brito, A.R.; Luiz-Ferreira, A. Chemical composition of Rosmarinus officinalis essential oil and antioxidant action against gastric damage induced by absolute ethanol in the rat. Asian Pac. J. Trop. Biomed. 2016, 6, 677-681. [CrossRef]

37. Pintore, G.; Usai, M.; Bradesi, P.; Juliano, C.; Boatto, G.; Tomi, F.; Chessa, M.; Cerri, R.; Casanova, J. Chemical composition and antimicrobial activity of Rosmarinus officinalis L. oils from Sardinia and Corsica. Flavour Fragr. J. 2002, 17, 15-19. [CrossRef]

38. Lo Presti, M.; Ragusa, S.; Trozzi, A.; Dugo, P.; Visinoni, F.; Fazio, A.; Dugo, G.; Mondello, L. A comparison between different techniques for the isolation of rosemary essential oil. J. Sep. Sci. 2005, 28, 273-280. [CrossRef] [PubMed]

39. De Martino, L.; De Feo, V.; Formisano, C.; Mignola, E.; Senatore, F. Chemical composition and antimicrobial activity of the essential oils from three chemotypes of Origanum vulgare L. ssp. hirtum (Link) Ietswaart growing wild in campania (Southern Italy). Molecules 2009, 14, 2735-2746. [CrossRef] [PubMed]

40. Vazirian, M.; Mohammadi, M.; Farzaei, M.H.; Amin, G.; Amanzadeh, Y. Chemical composition and antioxidant activity of Origanum vulgare subsp. vulgare essential oil from Iran. Res. J. Pharmacogn. 2015, 2, 41-46.

41. Daferera, D.J.; Ziogas, B.N.; Polissiou, M.G. GC-MS analysis of essential oils from some Greek aromatic plants and their fungitoxicity on Penicillium digitatum. J. Agric. Food Chem. 2000, 48, 2576-2581. [CrossRef] [PubMed]

42. Dadalioglu, I.; Evrendilek, G.A. Chemical compositions and antibacterial effects of essential oils of Turkish oregano (Origanum minutiflorum), bay laurel (Laurus nobilis), Spanish lavender (Lavandula stoechas L.), and fennel (Foeniculum vulgare) on common foodborne pathogens. J. Agric. Food Chem. 2004, 52, 8255-8260. [CrossRef] [PubMed]

43. Mazzarrino, G.; Paparella, A.; Chaves-López, C.; Faberi, A.; Sergi, M.; Sigismondi, C.; Compagnone, D.; Serio, A. Salmonella enterica and Listeria monocytogenes inactivation dynamics after treatment with selected essential oils. Food Control 2015, 50, 794-803. [CrossRef]

44. Raal, A.; Orav, A.; Arak, E. Composition of the essential oil of Salvia officinalis L. from various European countries. Nat. Prod. Res. 2007, 21, 406-411. [CrossRef] [PubMed]

45. Badiee, P.; Nasirzadeh, A.R.; Motaffaf, M. Comparison of Salvia officinalis L. essential oil and antifungal agents against candida species. J. Pharm. Technol. Drug Res. 2012, 1, 7. [CrossRef]

46. Dziri, S.; Casabianca, H.; Hanchi, B.; Hosni, K. Composition of garlic essential oil (Allium sativum L.) as influenced by drying method. J. Essent. Oil Res. 2014, 26, 91-96. [CrossRef]

47. Yu, T.H.; Wu, C.M.; Liou, Y.C. Volatile Compounds from Garlic. J. Agric. Food Chem. 1989, 37, 725-730. [CrossRef]

48. Thompson, J.D.; Chalchat, J.C.; Michet, A.; Linhart, Y.B.; Ehlers, B. Qualitative and Quantitative Variation in Monoterpene co-Occurrence and Composition in the Essential Oil of Thymus vulgaris Chemotypes. J. Chem. Ecol. 2003, 29, 859-880. [CrossRef] [PubMed]

49. Piccaglia, R.; Marotti, M. Characterization of some Italian types of wild fennel (Foeniculum vulgare Mill.). J. Agric. Food Chem. 2001, 49, 239-244. [CrossRef] [PubMed]

50. Sun, Z.; Wang, H.; Wang, J.; Zhou, L.; Yang, P. Chemical composition and anti-inflammatory, cytotoxic and antioxidant activities of essential oil from leaves of Mentha piperita grown in China. PLoS ONE 2014, 9, e114767. [CrossRef] [PubMed]

51. Saharkhiz, M.J.; Motamedi, M.; Zomorodian, K.; Pakshir, K.; Miri, R.; Hemyari, K. Chemical Composition, Antifungal and Antibiofilm Activities of the Essential Oil of Mentha piperita L. ISRN Pharm. 2012, 2012, 1-6. [CrossRef] [PubMed]

52. Mandal, S.; Mandal, M. Coriander (Coriandrum sativum L.) essential oil: Chemistry and biological activity. Asian Pac. J. Trop. Biomed. 2015, 5, 421-428. [CrossRef]

53. Miladi, H.; Slama, R.B.; Mili, D.; Zouari, S.; Bakhrouf, A.; Ammar, E. Chemical Composition and Cytotoxic and Antioxidant Activities of Satureja montana L. Essential Oil and Its Antibacterial Potential against Salmonella Spp. Strains. J. Chem. 2013, 2013, 1-9. [CrossRef]

54. Lo Cantore, P.; Iacobellis, N.S.; De Marco, A.; Capasso, F.; Senatore, F. Antibacterial activity of Coriandrum sativum L. and Foeniculum vulgare Miller Var. vulgare (Miller) essential oils. J. Agric. Food Chem. 2004, 52, 7862-7866. [CrossRef] [PubMed] 
55. Wang, H.F.; Hway, K.H.; Yang, C.H.; Huang, K.F. Anti-oxidant activity and major chemical component analyses of twenty-six commercially available essential oils. J. Food Drug Anal. 2017, 25, 881-889. [CrossRef] [PubMed]

56. Piluzza, G.; Bullitta, S. Correlations between phenolic content and antioxidant properties in twenty-four plant species of traditional ethnoveterinary use in the Mediterranean area. Pharm. Biol. 2011, 49, $240-247$. [CrossRef] [PubMed]

57. Çetin, B.; Özer, H.; Cakir, A.; Polat, T.; Dursun, A.; Mete, E.; Öztürk, E.; Ekinci, M. Antimicrobial Activities of Essential Oil and Hexane Extract of Florence Fennel [Foeniculum vulgare var. azoricum (Mill.) Thell.] Against Foodborne Microorganisms. J. Med. Food 2010, 13, 196-204. [CrossRef] [PubMed]

58. Mahboubi, M.; Kazempour, N.; Mahboubi, M. Antimicrobial activity of Rosemary, Fennel and Galbanum essential oils against clinical isolates of Staphylococcus aureus. Biharean Biol. 2011, 5, 4-7.

59. Tarek, N.; Hassan, H.M.; AbdelGhani, S.M.M.; Radwan, I.A.; Hammouda, O.; El-Gendy, A.O. Comparative chemical and antimicrobial study of nine essential oils obtained from medicinal plants growing in Egypt. Beni-Suef Univ. J. Basic Appl. Sci. 2014, 3, 149-156. [CrossRef]

60. Gachkar, L.; Yadegari, D.; Bagher, M.; Taghizadeh, M.; Astaneh, S.A.; Rasooli, I. Food Chemistry Chemical and biological characteristics of Cuminum cyminum and Rosmarinus officinalis essential oils. Food Chem. 2007, 102, 898-904. [CrossRef]

61. Burt, S. Essential oils: Their antibacterial properties and potential applications in foods-A review. Int. J. Food Microbiol. 2004, 94, 223-253. [CrossRef] [PubMed]

62. Pirbalouti, A.G.; Rahimmalek, M.; Malekpoor, F.; Karimi, A. Variation in antibacterial activity, thymol and carvacrol contents of wild populations of Thymus daenensis subsp. daenensis Celak. Plant Omics 2011, 4, 209-214.

63. Rota, M.C.; Herrera, A.; Martínez, R.M.; Sotomayor, J.A.; Jordán, M.J. Antimicrobial activity and chemical composition of Thymus vulgaris, Thymus zygis and Thymus hyemalis essential oils. Food Control 2008, 19, 681-687. [CrossRef]

64. Delaquis, P.J.; Stanich, K.; Girard, B.; Mazza, G. Antimicrobial activity of individual and mixed fraction of dill, celandra, coriander and eucalyptus essential oil. Int. J. Food Microbiol. 2002, 74, 101-109. [CrossRef]

65. Paparella, A.; Taccogna, L.; Aguzzi, I.; Chaves-López, C.; Serio, A.; Marsilio, F.; Suzzi, G. Flow cytometric assessment of the antimicrobial activity of essential oils against Listeria monocytogenes. Food Control 2008, 19, 1174-1182. [CrossRef]

66. Serio, A.; Chiarini, M.; Tettamanti, E.; Paparella, A. Electronic paramagnetic resonance investigation of the activity of Origanum vulgare L. essential oil on the Listeria monocytogenes membrane. Lett. Appl. Microbiol. 2010, 51, 149-157. [CrossRef] [PubMed]

67. D'Amato, S.; Serio, A.; Chaves-López, C.; Paparella, A. Hydrosols: Biological activity and potential as antimicrobials for food applications. Food Control 2018, 86, 126-137. [CrossRef] 